\title{
The Relevance of Multicultural Approach Through Social Studies Education
}

\author{
Bambang Subiyakto \\ Social Studies Education Department \\ Universitas Lambung Mangkurat \\ Banjarmasin, Indonesia \\ phetex73@yahoo.com
}

\author{
Heri Susanto \\ History Education Department \\ Universitas Lambung Mangkurat \\ Banjarmasin, Indonesia \\ Mutiani \\ Social Studies Education Department \\ Universitas Lambung Mangkurat \\ Banjarmasin, Indonesia
}

\begin{abstract}
The factual condition describes how the social condition of Indonesian society is increasingly critical. This is triggered by a variety of unresolved social problems. Social problems become the scourge of homework together. A multicultural approach integrated with Social Studies (IPS) Education learning offers an alternative through the application of diversity-based educational strategies and concepts existing in the community. This paper aims to describe theoretically how to integrate multicultural and IPS approaches. Thus, the portion of multicultural education and IPS is able to provide learners with sensitivity in the face of symptoms and social problems rooted in differences. The differences are such as tribe, race, religion, and values that occur in the community environment for the cultivation of unity. Therefore, the substance and model of this learning will be able to focus the study on the appreciation of cultural diversity.
\end{abstract}

Keywords: social problems, multicultural approaches, and social studies education

\section{INTRODUCTION}

An archipelago is a place of the major religions in the world. The spread of these great religions cannot be separated from the geographical location of the archipelago in the world of trade since the early centuries. Not surprisingly, the influence of the spread of Hinduism, Buddhism, Islam, Catholic, Christianity, and other religions. Based on its development, historical notes then formed the sub-ethnic in Indonesia so that it has its own culture. In cultural perspectives, the ethnic diversity is not only maintained and developed within the territory where ethnic concentration exists but has also spread throughout the region.

The diversity that becomes the grace of Indonesia demands it to build a multicultural democraticsociety, which is definitely, demand the national education system that can build such a society. This means that the national education system should refer and apply the process to realize the goal. In Indonesia nowadays, numerous efforts have been formulated and tried to bring this goal to reality. The embodiment has been supported by the recognition of the existence of pluralist society and nation of Indonesia and the recognition of regional autonomy, a new experience that needs to be scrutinized and perfected continuously.

In this regard, social studies (IPS) education appears as a subject that provides instruction on the development of intellectual and social competence. Focusing on social skills is one factor developed as a competence that must be mastered by students. This skill will lead to the process of searching, selecting, processing, and using information. This process will be able to empower themselves to become responsible Indonesian citizens.

The context of IPS Education gives space for the formation of democratic students. This is in line with the need for a pluralistic shield of the State of Indonesia. Therefore, according to [1], IPS subject is grouped into two aspects namely (1) the ability to develop the concept of social life, and (2) the ability to apply the concept of social life through the practical learning experience. Both of them should be used as a guidance and reference in daily activities so that by learning IPS, students can develop their social skills in accordance with the expected competencies.

\section{RESULT AND DISCUSSION}

\section{A. Social Problems Perspective and Multicultural Approach}

The basic identity arises in social interactions among ethnic groups. The agents of the interactions of different ethnic groups will realize that there are group differences among them. The basic identity then becomes a distinction among these various ethnic groups that are interacting. The basic identity is the source of a primordial bond, a bond born of family relations or blood relations (lineage), race relations, religious or religious environment, as well as a particular language or dialect. An equation of blood relations, dialects, races, habits and so on which gave rise to emotional bonds [2]. 
Excessive levels can become something that is destructive. The bonds of Geertz can be considered as "inheritance" from the existing social nature. A "continuous continuity" and largely a family bond, but more than that, it is a heritage derived from birth in the midst of certain religious communities, speaking in a particular language dialect, and following certain social practices [3].

The everyday life of the basic identity of an ethnic group is often manipulated [4]. The basic identity can be deactivated, activated, or narrowed down because the basic identity is not something that is permanent or as hard as a stone but it is like liquid. In other words, it can flow and develop in order to have adjustments in life. In certain circumstances, the basic identity which manifests its existence in the form of primordial bonds gives rise to powerful emotional cohesion or excessive ethnocentrism, thus becoming a source of disaster.

Building a multi-ethnic and cultural society like Indonesia demands a new point of view. A pluralistic and multicultural society is impossible to build without the intelligent and moral human being. Culture in social life is very important because it becomes an adhesive tool within a community. Therefore, every country needs cultural politics [5]. Cultural politics can be done through provocation of "education".

According to [6], some of the education leads more to teaching how to think rather than what is thought. He further explained that students should be taught to understand all kinds of knowledge and actively discuss knowledge construction and different interpretations. In fact, a good learner is one who always learns all knowledge and participates actively in discussing the construction of knowledge. Students also need to be made aware that in the received knowledge that there is a wide range of interpretations that are determined by the interests of each of them. They should be accustomed to accepting differences. This is due to educational environment is a system consisting of many key factors and variables, such as school culture, school policy, politics, and the formalization of the curriculum and field of study. When there is any change, the change focuses more to create and maintain the school environment in an effective multicultural condition.

Every student should adapt to a multicultural school environment. The main purpose of multicultural education itself is to change the learning and learning approach toward giving equal opportunities to every student. Students are taught lateral thinking, diversity, and uniqueness to be appreciated. This means there must be a change in attitudes, behaviors, and values, especially the academic community of the school. When students are from their different backgrounds, they must learn from each other, interact and communicate, so as to accept the differences among them as something that enriches them.

\section{B. Study of IPS Education Conception}

Social Sciences (IPS) Education is a subject at primary and secondary school levels or one of the study programs in the university is identical with the term "Social Studies". The term IPS in elementary school is the name of a stand-alone subject as an integration of a number of concepts of social science, humanities, science and even social issues. IPS material for elementary school level is not seen in the discipline aspect because the more important is the pedagogic and psychological dimensionsas we all the characteristic of students' thinking ability which is holistic [7].

Based on some definitions and understanding of Social Studies (IPS) as have been stated by some experts above, it can be concluded that Social Studies (IPS) is one of the subjects that combines basic social science concepts such as geography, history, anthropology, and psychology to be taught at the level of education. Definition of the word learning and the definition of the word IPS as have been described above in joining into one sense then IPS learning is an effort made deliberately by educators to convey science related to social issues and citizenship to be taught in every level of education using the method and effective and efficient learning model.

IPS is an integrated study material that is a simplification, adaptation, selection, and modification organized from the concept of History, Geography, Sociology, Anthropology and Economics skills. The existence of IPS subject in elementary school students are expected to have knowledge and insight about the basic concepts of social science and humanities, have sensitivity and awareness of social issues in their environment, and have skills to study and solve social problems.

IPS lessons emphasize on the "education" aspect of the concept transfer because in Social Studies students are expected to gain an understanding of a number of concepts and develop as well as train their attitudes, values, morals, and skills based on the concepts they have. IPS also discusses the relationship between humans and their environment. It is the community environment in which the students grow and develop as part of society and faced with various problems in the surrounding environment [8].

The National Council for Social Studies (NCSS), as an organization of Social Studies experts, has been the source of reference for formulating the Social Studies learning objective of developing students to become citizens with knowledge, values, attitudes, and skills to participate in democratic life where the course content is excavated and selected based on history and social sciences, as well as in many respects including humanities and sciences [9].

The two main objectives of Social Studies learning are inseparable, integral, interconnected, and complementary. Social Studies have a helpful role in preparing democratic citizens with the cultivation of nationality and citizenship values supported by the mastery of the disciplines of the social sciences. The purpose of this research is so that students can have knowledge and insight about basic concepts of social sciences and humanities, have sensitivity and awareness of social problems in the environment, and have the skills to study and solve social problems.

\section{Multiculturalism and IPS Subject}

Indonesia is known as a multicultural country that should be able to provide anticipative and responsive to the phenomenon of cultural heterogeneity. The differences that have existed have caused a negative impact of conflict. One of 
them is caused by the heterogeneity or social differentiation of society [10]. Multiculturalism recognizes the differences in society, where the differences are not just descriptive differences but also normative differences. These differences are understood not only known but must be realized in an egalitarian life.

Perspectives of multiculturalism being in accordance with subjects taught at school can serve as a meaningful medium for the development of public awareness. In particular, IPS education is an effective tool for instilling multicultural awareness. One mission of IPS education at elementary and secondary school levels is: to equip students with a set of knowledge, attitude, values, moral, and life skills that are useful in understanding themselves and environment of the nation and country [11]. The environments referred to in this context are, among others, the ethnics, religions, races, ethnics, and languages diversity present in Indonesian. Education that has been invested in the curriculum of elementary education to universities has presented the concept of diversity. However, the implementation of IPS education has not yet been optimal in emphasizing education about diversity that is normative.

IPS education taught in schools, in general, does not revive good multicultural education, even tends to be counterproductive. This condition is similar to religion subject, that social conflicts are often hardened by religious legitimacy taught in the religion subject in conflict-prone regional schools". According to [12], many ethnics and ethnic conflicts that occur in some areas are stimulated by the lack of public understanding of multiculturalism nationality so that the effort of planting and internalization of cultural diversity for the community is a must so that the nation stays firm.

Attitudes toward multiculturalism require a cautious and tolerant soul and attitude. Continuous efforts in order to increase understanding and literacy awareness of multiculturalism, especially through education are done. During this time, the education of new diversity has been made as one of the subjects in the sub-subject of several subjects in elementary and secondary education, as in Social Studies subject.

IPS education itself studies social life based on geographical, economic, historical, anthropological, sociological, and state system studies, featuring subjects that study human beings in all aspects of life and their interactions in society. In order to achieve the objectives which have been set required teachers who teach Social Studies subject in junior high school with adequate skills and skills or in other words have competence in that field. IPS education material as stated by [13] is sourced from the social sciences as presented at the university level, just because of the consideration of the level of intelligence, the maturity of students, the educational material is simplified, selected, adapted and modified for the purpose institutional primary and secondary education. The role of IPS is crucial to educating students to illustrate knowledge, attitudes, and skills in order to take an active part in their future lives as members of society and good citizens.

\section{CONCLUSION}

Cultural diversity in Indonesia is a historical and social reality that is hardly denied. The uniqueness of these diverse cultures provides the implications for everyone's mindset, behavior, and personal character as a living tradition in society and the region. This is due to the traditions formed are different from one tribe/area to another tribe/region. The existence of intercultural opens conflicts opportunities whenever there is not any mutual understanding and respect for each other. As a result, the process to minimize this conflict is needed. It requires a multicultural educational effort in order to empower a pluralistic and heterogeneous society to understand and respect each other and to form an open character to the differences.

The lessons to open insights into the understanding of differences are presented through educational "provocation". Among the subjects presented in the curriculum, IPS education subject is a form of social studies interpreted as a review of society. The role of IPS education subject is crucial to educating students describing knowledge, attitudes, and skills in order to take an active part in their future lives as members of society and good citizens. This subject is developed to accommodate social problems that exist in the community. Further, it makes students to be more responsible, both to themselves and to others or the environment.

In a nutshell, IPS education subject is a very important subject to be taught because it is directly related to the formation of good citizen behavior. They are the citizens who have useful abilities and skills for themselves in everyday life. They are also the citizens who are proud as parts of the nation of Indonesia, and those who love the homeland. It is concluded that social studies education has a purpose to develop knowledge, attitude, and social skills in the form of concepts and learning experiences selected or organized in social studies.

\section{REFERENCES}

[1] G. Arif, Remaja dan Permasalahannya, Yogyakarta: Hanggar Kreator, 2011.

[2] C. Geertz, Tafsir Kebudayaan, Yogyakarta: Kanisius, Yogyakarta, 1992.

[3] S. Isaac. andB. M. William, Handbook in Research and Evaluation. $3^{\text {rd }}$ Ed, San Diego California: Educational and Industrial Testing Services, 1997.

[4] D. J. Cohen and F. R. Volkmar, Handbook of autism and pervasive developmental Disorders, $2^{\text {th }}$ Ed, USA: John Wiley \& Sons Inc, 1997.

[5] L. E. Harrison andS. P. Huntington, Culture Matters: How Values Shape Human Progress, New York: Basic Books, 2000.

[6] A. J. Banks, Teaching Strategies for the social Studies: Inquiry, Valuing, and Decision-Making, New York, Longman, 1993.

[7] Sapriya, Pendidikan IPS, Bandung: PT. Remaja Rosdakarya, 2009.

[8] Pusat Kurikulum Balitbang, Kurikulum Berbasis Kompetensi Mata Pelajaran IPS SMP, Jakarta: DEPDIKNAS, 2001.

[9] National Council for the Social Studies, The Curriculum Standards For Social Studies: Expectation For Excellence, USA: Library Of Congress Cataloging, 1994.

[10] A. M. Fadjar, Holistika Pemikiran Pendidikan, Jakarta: Radja Grafindo Persada, 2004.

[11] H. Hamid, Evaluasi Kurikulum, Bandung: Remaja Rosdakarya, 2008.

[12] H.A.R. Tilaar, Kekuatan dan Pendidikan, Jakarta: Grasindo, 2004. 
[13] Saidihardjo, Pengembangan Kurikulum Ilmu Pengetahuan Sosial (IPS),Yogyakarta: Program Pascasarjana Universitas Negeri Yogyakarta, 2004. 